\title{
PREACHING AND EVANGELISM
}

Dirk D. J. Hart. CRC, VSA.

In the New Testament any follower of the Way could preach, declare good news. Luke reports that Jesus said to someone, "Follow me." But the man wanted first to bury his father. Then Jesus said, "Leave the dead to bury their own dead; but as for you, go and proclaim the kingdom of God" (Luke $9: 59,60$ ). Jesus sent the disciples out on a preaching and healing mission (Matthew $10: 5$; Mark $6: 7$ ) and also the seventy. The Gadarene demoniac is told, "Go home to your friends, and tell them how much the Lord has done for you, and how he has had mercy on you" (Mark 5:19). The disciples are charged with preaching the Gospel to the whole world (Matthew 16 : 19; Mark 16:15; Luke 24:47, 48; John $20: 21$; Acts $1: 8$ ). Persecuted believers are scattered "and went around preaching the word" (Acts $8: 4 ;$ cf. $15: 35$ ). In order that the Apostels can devote themselves "to prayer and to the ministry of the word" seven men are chosen to administer the daily distribution of food (Acts $6: 1-6$ ). But at least two of these men turn out to be preachers also (Acts 7 and $8: 5$ ). The Thessalonian believers "sounded forth" the word of the Lord everywhere (Thessalonians $1: 8$ ). All this is summarized in the familiar words of 1 Peter $1: 9$, "But you are a chosen race, a royal priesthood, a holy nation, God's own people, that you may declare the wonderful deeds of him who called you out of darkness into his marvellous light."

Today we have a more restricted understanding of preaching: we mean by it the exposition and application of Scripture by an authorized and ordained minister under the supervision of the elders. Charism has become office.

In the New Testament, evangelism understood as bringing good news with a view to conversion, was not a subject to be debated and endlessly defined. It was as natural as eating and breathing. All of the theology of the New Testament comes out of the missionary context. As Christ was sent into the world, so is the church. The question of evangelism never comes up. The heart-beat of the church was in missions and evangelism. In the intervening years, however, this too changed. There arc all kinds of historical reasons for this not the least of which is the tremendous success which the church enjoyed until it became the majority faith in many lands and constantinianism established it.

In Reformed theology a distinction has often been made between missions and evangelism. Missions is considered to be gospel outreach to those who have never heard the Gospel or to those who are far away geographically or culturally. Evangelism is construed to be gospel outreach to those who have strayed from the covenant and those who are most like ourselves ethnically and geographically. I 
have searched in vain for the origin of this distinction or its biblical warrant. I know it was widely held by Dutch theologians in the first half of this century and is still held by Die Gereformeerde Kerk van Suid-Afrika. This distinction is useful in so far as it helps us to tailor the communication of the eternal Gospel to the needs, circumstances and backgrounds of those to whom we preach. But on the whole the distinction only confuses a work that is already too much restricted by distinctions, theological pronouncement and ecclesiastical inversion. There is only one Gospel to be preached. This Gospel is the power of God for salvation to everyone who has faith (Romans $1: 16$ ).

It would be of great benefit to the spiritual health and vitality of the church if we could let go of some of our officiousness, our love of control by rules and regulation, the theological walls we build around the Gospel and recapture the New Testament atmosphere in which preaching and evangelism could be and was the task of all. We need to read again Roland Allen's The Spontaneous Expansion of the Church. By "spontaneous expansion" he meant, among other things, "the unexhorted and unorganized activity of individual members of the church explaining to others the Gospel which they have found for themselves" (p. 7). He goes on to say, "Whether we consider our doctrine, or our civilization, or our morals, or our organization, in relation to a spontaneous expansion of the church, we arc seized with terror, terror lest spontaneous expansion should lead to disorder" (p. 13). In the church today we need to ask in all seriousness whether our love for order and control has quenched the Spirit who first came upon the church in a rushing mighty wind and in due time toppled the temple and built a new temple wherever men and women called upon the Name of the Lord.

\section{THE COVENANTAL CONTEXT}

We shall keep these things in mind as we turn more specifically to the topic preaching and evangelism. By preaching now is meant the explanation and application of the Word of God, the Bible, as that is addressed to God's people gathered for public worship, usually on Sunday, with a view to the edification of believers. By evangelism is meant this same explanation and application of the Scriptures with a view to the conversion of the uncommitted.

It is important to see the larger context of preaching and evangelism. Both are distinctly covenantal activities. God has sovereignlyraised up a covenantal people, reconciled them to Himself by His Son and revealed Himself by the inspired Word. His people are to grow up to maturity and to be equipped for ministry (Ephesians 4: 11-16). The covenant has universal dimensions and intentions. The promises of the covenant are not only to "you and to your children" but also "to all that are far off." God has His elect people everywhere and among all peoples, "everyone whom the Lord our God calls to Him" (Acts 2:39). The Great Commission of Matthew 28 is a republication of God's promise to Abraham that "all peoples on earth will be blessed through you" (Genesis 12:3). This was, says the Apostle Paul, "The preaching of the Gospel beforehand to Abra- 
ham" so that all who have faith may claim Abraham as their father (Galatians 3:6-9). Those who formerly were strangers to the covenant and therefore separated from Christ have "been brought near in the blood of Christ" (Ephesians $2: 12,13$ ). By His coming, Christ has brought to an end all hostility and division between those of every language race and nation who have faith and made them members of one body, the household of God. The message that brings them together is thc same for all: "And He came and preached peace to you who were far off and peace to those who were near" (Ephesians $2: 13-22$ ). Seen from the perspective of the covenant, therefore, preaching and evangelism are inseparably connected.

\section{THE DIMENSION OF WORSHIP}

Preaching and evangelism also have their own primary context. Preaching is done in the context of public worship of the church and evangelism is done in the context of the mission of the church, with mission here understood as all that the church is sent to do and say in ministry to the world.

There is nothing more characteristic of God's people than that they worship the Triune God from whom all blessings flow. Our entire lives are to be lived as liturgies of love to God in response to Jesus Christ. This is the proper covenantal response to God. When God published the covenant to Abraham we read "Then Abraham fell on his face" (Genesis $17: 3$ ). This response is further described by Paul when, having lauded the depths of the riches and wisdom and knowledge of God and ascribed to Him glory forever (Romans 11 : 33-36), he says, "I appeal to you therefore, brethren, by the mercies of God, to present your bodies as a living sacrifice, holy and acceptable to God, which is your spiritual worship" (Romans $12: 1$ ). Similarly, the Apostle Peter urges his readers to be "built unto a spiritual house, to be a holy priesthood, to offer spiritual sacrifices acceptable to God through Jesus Christ" (1 Peter 2:5).

The response of worship in the totality of life comes to full expression in the public, corporate worship of the gathered congregation. This public corporate praise of God has its roots in tabernacle and temple worship and continues for the people of God who are "grateful for a kingdom that cannot be shaken and thus ... offer to God acceptable worship with reverence and awe" (Hebrews 12:8). The congregation gathered for worship is in many ways the address of the church where it may be found at home and at its best.

The greatest sin in worship is to be boring, apathetic or clull and to be so predictable and safe in the order of events that all sense of expectation is gone and no surprises are possible. Particularly churches that pride themselves in being "non-liturgical" can be so rigid in what may and may not happen in the service that it seems the Holy Spirit must feel strait jacketed by our patterns.

In corporate public it is God who calls the meeting. He sets Christ center stage and He says "Let's talk." God's praise is sung. $\mathrm{He}$ is adored. The worshippers bring their entire lives and offer them to God. God says: "Grace to you and peace..." and the people re- 
spond, "Holy, holy, holy, Lord God Almighty! Early in the morning our songs shall rise to Thee." There is intercession and thanksgiving. The high voltage of the Spirit can scarcely be contained in the acts of worship so that we adore Him even speechlessly or, alternatively, are struck dumb by our lack of conformity to God's law only to hear a new God's forgiveness through Jesus Christ. There is instruction, encouragement and consolation from God's Word. There is an intensity about all this that can scarcely be obtained by worship in solitude. God's people are a body with many members. Christ is present in a special way where more than the individual gather for worship (Matthew 18:20). If we embrace God it is only because He has first embraced us as part of His people and incorporated us, by baptism, into His covenant people. There is, therefore, a primary vertical dimension in worship which gives public worship its unique power. The people respond and God continues to speak and act.

There is, however, also a strong horizontal bond in public worship. It is, after all. corporate worship. The book of Hebrews emphasises this when it says. "Let us consider how to stir up one another to love and good works, not neglecting to meet together, as is the habit of some, but encouraging one another, and all the more as you see the Day drawing near" (Hebrews $10: 24,25$ ). We therefore embrace not only God, but one another: "He who does not love his brother whom he has seen cannot love whom he has not seen. And this commandment we have from him, that he who loves God should love his brother also" ( 1 John $4: 20,21$ ). In the worship service, distinctions of class or kind fall away between those who love God. Else we make distinctions among ourselves "and become judge 3 with evil thoughts" (James 2:1-9). The worship service is not only "the assembly of the first-born enrolled in heaven" but there is communion there too with "innumerable angels in festal gathering" (Hebrews $2: 22,23)$. The cohering reality of it all is in Jesus Christ who is both eldest brother and Lord.

Worship is something we do, we engage in it. Body and soul are stretched; heart and voice are heard. We are not simply audience but actors. And we bring into worship everything we are as citizens of a heavenly kingdon! who are in the world but yet not of it. In public worship the church is to be seen at its best: faith, hope and love are in full bloom; grace, mercy and peace shine. There is a seamless robe of fellowship there between sisters, brothers and their Redeemer with on it the words "healed and forgiven."

It is for these reasons that worship has tremendous evangelizing power. There are many believers today who can testify that the first conscious stirring of the Holy Spirit in their lives came as a result of what they felt and observed in a public worship service. The welcome they received, the friendship that was offered, the concrete joy that was present motivated, them, in turn, to listen to what was said and to respond in repentance and faith. Genuine Christian worship demonstrates what cannot be observed and heard anywhere else in the world: Spirit and truth (John $4: 24$ ). 


\section{THE DIMENSION OF MISSION}

But there is more to this connection between preaching and evangelism. The church of God is an apostolic, missionary people. As Christ was sent into the world, so too His people are sent. The same Spirit which once was given to Christ without measure is now given to His people (John 20:21,22). The covenantal promise "all peoples of the earth will be blessed through you" (Genesis 12:3) is republished when Jesus said, "you will be my witnesses... to the end of the earth" (Acts $1: 8$ ).

This essential missionary nature of the church is not something that can be turned off or on. The mission of the church is at the heart of what it means to be God's people. In fact, worship rises from mission, participates in the work of this mission and leads to mission. God is a missionary, evangelizing God who calls unto Himself a missionary, evangelizing people who worship Him while on their missionary pilgrimage.

Because as we have said earlier, the address of the church where it may be found at home and at its best is at the gathering of God's people for public worship, the erroneous impression is often left with God's people that the only business of the church is worship and the edification of those who are already believers. About this Paul Hoon in The Integrity of Worship writes. "Materials commonly used in worship reinforce this inversion and edify the congregation in a bad rather than in a good sense. Many church rites, prayers, responsive readings, invitations to worship ... reinforce a congregation's preoccupation with itself" (p. 332). He adds, "An unlearning of the esse of the Church as only cultic and a relearning of the esse of the Church as also apostolic may need to be the first order of business, and in very practical ways. This may require for one thing a change in strategy whereby the pastor reconceives his priorities, first sensitizes the layman to experiences of ministry in the world, and then works inductively into the meaning of liturgy. And as long as liturgical action is understood as having integrity only insofar as it embraces both, and as long as the presence of Christ is understood as the source of the life and the shape of the mission the lay. man lives out in the world, such an approach may be indicated" (pp. $333,334)$.

\section{PREACHING GOOD NEWS}

Having set preaching and evangelism in their contexts of worship and mission and asserted that these two essential tasks of the church may not be practised in isolation from one another, how does this affect the week by week preaching? Evangelism is, at its simplest, preaching good news. And preaching good news is the centerpiece in the Reformed worship service. Preachers and books on preaching tend to qualify sermons in many different ways. A preacher may be preaching a doctrinal sermon or catechism sermons or a series of sermons on the Apostel's Creed or expository messages on a book of the Bible. He may be preaching "through the Bible" with one ser- 
mon on each of the sixty-six books of the Bible or a series of messages on Old Testament characters. Sermons may be topical or semitopical in nature such as when the preacher deals with marriage and family life. The great moral problems of our day such as abortion, nuclear armaments, sexual behaviour, and materialism may be dealt with. The pulpit cannot and may not ignore the social and political questions that are faced nationally and internationally. But all these sermons will have in common that they are Gospel preaching: the good news of Jesus Christ crucified, risen, ruling and coming again.

Sermons will warn. teach, exhort, comfort, inspire, encourage, motivate, convince, stimulate, lead to decision, and build up the saints-and in doing these things they will always be Gospel: the good news of Jesus Christ.

"It is my contention" writes John R. W. Stott, "that all true Christian preaching is expository preaching" (Between Two Worlds: The Art of Preaching in the Twentieth Century, p. 125). The classic Reformed method is to take one or more verses of Scripture, distill the central theme and then organize the material with several subdivisions. Application may be made throughout the sermon or primarily at its conclusion. Add an introduction, and the sermon is ready to be preached. It must be emphasized, however, that what is preched must not be merely the verse or verses, but the entire Word of God and therefore Jesus Christ. Mere moralizing diminishes our Lord and counterfeits the Gospel. Believer and unbeliever alike will be exhorted to trust Jesus Christ as the only way to God.

There is only one Gospel - only "one body and one Spirit... one hope... one Lord, one faith, one baptism, one God and Father, who is above all and through all and in all' (Ephesians $4: 4,5,6$ ). There is not one Gospel for the world and one for the church, therc is not one gospel for the covenant backslider and one for the pagan. As Paul says so graphically to the Galatians, "But if we or an angel from heaven should preach to you a gospel contrary to that which we preached to you let him be accursed. 0 , foolish Galatians, who has bewitched you before whose eyes Jesus Christ was publicly portrayed as crucified?" (Galatians $1: 8,9$ and $3: 1$ ).

Unbelievers in the pew must hear this Gospel loud and clear. If they do not hear it and go home accursed, it is the church and the preacher who, according to Ezekiel and Paul, have blood on their hands (Ezekiel 33:1-9, Acts 20:26, 27). Joyful and celebrative as worship must be, varied and broad as preaching may be, they are at the same time a matter of life and death.

\section{PREACHING AS TEACHING}

The Scriptures do distinguish in the matter of preaching and teaching between milk and meat. Paul explains to the Corinthians that they were as yet babes in Christ, in need of milk and still not ready for meat (1 Corinthians 3:1,2). And the writer to the Hebrews wants to go on from elementary and foundational teaching to matters that lead to maturity (Hebrews $6: 1$ ). I do no propose that the 
missionary nature of the church and the inevitable evangelistic dimension of preaching demand that sermons always be milk. The people of God do need to be fed the meat of the Gospel in order to grow to maturity. I would like to make some observations about this, lest we think that the evangelistic interest of the church will limit the preacher to the abc's of the gospel.

In the first place, the people of God, believers and their children, gathered for public worship are always a mixture of the spiritually mature, the immature and the unconverted. The milk of the gospel may never be missing, therefore. Secondly, the spiritually mature who can be fed spiritual meat but who complain when the abc's of the gospel are proclaimed thereby call into question their maturity. The believer's ear never tires of hearing Christ proclaimed as crucified, risen, ruling and returning. The call to conversion is applicable to all since we believe that conversion is not only the initial turning to God but equally a life-long process of sanctification (cf. Heidelberg Catechism, Lord's Day 33). The genuinely mature believer will pray for and expect that in the worship service there is room for the beginning of faith on the part of the uncommitted. In this connection D. Martin Lloyd Jones issues an important warning: "I am urging that all the people who attend a church need to be brought under the power of the Gospel. The Gospel is not only and merely for the intellect; and if our preaching is always expository and for edification and teaching it will produce church members who are hard and cold and often harsh and self-satisfied. I do not know of anything that is more likely to produce a congregation of Pharisees than just that (Preaching and Preachers, p. 152, 153).

The third observation in connection with feeding spiritual meat to the congregation is this: meat is best digested in little pieces, one bite at a time. The pulpit is no place for a display of abstract theological learning and a scholar's vocabulary. We must disabuse the congregation from the notion that "deep" is the same as difficult and the real Reformed teaching is that which goes over the heads of most people. It is a perpetual challenge for the preacher to preach gospel meat in a simple, transparent way. Finally, we need to remember that spiritual maturity come not only by right learning but also by right practise. Orthodoxy and orthopraxis belong together.

I take it to be the teaching of Ephesians 4:11-16 that the "measure of the stature of the fulness of Christ" comes at least in part as the saints minister to one another and to the world in word and deed. It is the universal experience of the church, for example, that those members who learn to articulate the faith to their neighbours find this to be a significant means of grace and growth in their own lives.

The relationship between preaching and evangelism demands that the congregation is well instructed in the nature of the church as God's missionary people. This will require preaching on the Biblical texts which teach this A series of sermons on the book of Acts, for example, is one way to do this. It is important for the congrega- 
tion to be oriented to its evangelistic task and the consequences of this for worship so that pew and pulpit act on the same assumptions and live by the same expectations.

Paradoxically, the relationship between evangelism and preaching also requires that there be a careful balance between what may seem to be self-serving concerns and concern for others. The church does not exist for the world nor does the world set its agenda. The church exists for God. He sets the agenda. It is God's aim to restore the fallen creation to set it "free from the bondage to decay" (Romans $8: 21$ ). To that end He sent His Son into the world and gave to the church His Spirit as a guarantee of the full inheritance to come (Ephesians 2:13,14). Already all things are under Christ's feet (Ephesians 3:22). Until the time comes for the completion of all things and every knee shall bow to God and give Him praise (Philippians 2:11) there is an interim agenda for the church. It is to acknowledge Christ's universal authority and therefore to make disciples of all nations (Matthew $28: 18,19$ ). It is a mistake, therefore, for the church to be preoccupied with itself, to be ecclesiocentric. Rather, the church is pre-occupied with its Lord and His authority over all things and concern for a new creation. Preaching reflects this and lets the light of the Gospel illumine all the various questions, trends, problems and issues with which the world struggles. It is in the light of the Gospel that sin appears at its shabbiest, that the idolatry of our political ideologies is laid bare, that injustices are clearly seen, that our vaunted power structures are exposed as demonic. Jesus is Lord! That confession has consequences for our personal lives as wcll as all of life. This preaching of Christ's Lorclship establishes a beachhead in the hearts of individuals-hence even when Gospel preaching highligts the cosmic dimension of the kingdom, such preaching, must often be accompanied by the demand for personal repentance and faith and the promise of etcrnal life (Romans $14: 16$ ).

\section{INVITATIONAL PREACHING}

Does the relationship between preaching and evangelism demand an invitation, the so-called altar call? In the Reformed tradition, altar calls of any kind have always been avoided. Grace is sovereign and does not depend on emotional manipulation. The entire "invitation system," as it has been called by Iain Murray in a book bv that title, rests on an Arminian theology of human autonomy and free will. In some fundamentalistic quarters the giving of an altar call is axiomatic - one simply has not preached the Gospel without it. In the Reformed churches we need to examine our opposition to this and ask whetker our neglect of assuring an invitation is based on a rejection of methodistic and Arminian extremes or on our understanding of the Gospel.

For all his opposition to the invitation system, Iain Murray says quite rightly, "There is no discussion about whether it is right to invite men to come to Christ. That issue should be indisputable to 
those who believe Scripture. Nor is it an open question whether man's responsibility to repent and believe should be emphasized in evangelism. Without such an emphasis there can be no evangelism at all in any biblical sense of the word" (The Invitation System, p. $6)$.

The Gospel is by nature invitation. Jesus invites and says, "Come" (Matthew 11:28). Because He is Lord, the invitation is also a command. Preachers should not hesitate to stress the invitation and command. The church which takes its evangelistic mandate seriously will from time to time make that demand very specific and indicate how those who are led by the Spirit to respond may make this known and seek further help. It is instructive to read what D. Martin Lloyd-Jones says about this. After extensively dealing with the error of the altar call he nevertheless says, "The appeal should be implicit throughout the whole body of the sermon, and in all that you are doing I would say, without hesitation, that a distinct and separate and special appeal at the end after a break, and after a hymn, should only be made when one is conscious of some overwhelming injunction of the Spirit of God to do so. If I feel that, I do it; but it is only then. And even then the way which I do it is not to ask people to come forward; I just make it known that I am ready to see them at the end of the service or at any other time. Indeed, I believe that the minister should always make an announcement in some shape or form that he is available to talk to anybody who wants to talk to him about their soul and its eternal distiny" (Preaching and Preachers, p. 282).

Before I come to the conclusion on the subject, the question arises whether the preacher should exhort people to be diligent witnesses and evangelists in their daily life, work and relationships In so far as this is taught in the Scriptures he should without a doubt do so. But only if the preacher himself is prepared to be a model and preferably is prepared to take along one or more members on his evangelistic visitation. If the preacher is not prepared to do this, the congregation will not either. All preachers should ponder again what Paul says to Timothy: "I charge you in the presence of God and of Christ Jesus who is to judge the living and the dead, and by his appearing and his kingdom: preach the word, be urgent in season and out of season; convince, rebuke, exhort, be unfailing in patience and in teaching ... do the work of an evangelist, fulfil your ministry" (2 Timothy $4: 1-5$ ).

\section{CONCLUSION}

Having examined now the relationship of the church and preaching in the light of the missionary nature of God's people, I urge you let the church open wide its doors and invite and expect people of every kind, class and color to taste and see that the Lord is good and His mercy extends over all He has made. I am saying this for the good of the church, for its growth, and for Christ's sake who did not reject the adulterous woman at the well, or the children, or the tax col- 
lectors or any of sinners who sought Him out. Indeed, he was not content to wait for them, but sought them out.

I do not mean at all to say that evangelism or evangelistic concerns should somehow take over the worship service. There will always be a sense in which the unbeliever is an outsider looking in. True worship is an act of those whose hearts are made right by faith in Christ. The integrity of worship may not be destroyed by making the service into a gospel crusade rally. But it is precisely the integrity and power of such true worship accompanied by the preaching of God's Word that will lead the inquirer to conversion and declare "God is really among you!" (1 Corinthians 14:25).

All this has tremendous practical consequences for everything that happens before, during and after the worship service. We need, in the light of the missionary nature of God's worshipping people, not only to examine preaching but also such things as the welcome extended to members and visitors, the announcements made in bulletin and service, the prayers, the celebration of the sacraments and the hymns that are sung.

In Matthew's Gospel there are two occasions in which Christ promises His continued presence - a presence which is at the heart of covenantal life. In the first instance he says "Where two or three are gathered in my name, there am I in the midst of them". (Matthew $18: 20$ ). The second time is when Jesus met His disciples in Galilee following His resurrection. There, we read, "They worship him" and Jesus declared to them His authority, commanded them to disciple the nations, baptizing and teaching them, "and lo, I am with you always, to the close of the age" (Matthew 28:17-20). Thus Christ joins, with the promise of his presence, these two contral tasks of the church: worship and mission.

Presentation to the Reformed Theological Society of Witwatersrand on October 24, 1983.

\section{BOOKS CITED}

Roland Allen, The Spontaneous Expansion of the Church; Grand Rapids, Wm. B. Eerdmans Publising Co., 1962. Pb. 158 pages.

Paul Waitman Hoon, The Integrity of Worship; Nashville, Abingdon Press, 1971, 363 pages.

D. Martin Lloyd Jones, Preaching and Preachers; Grand Rapids, Zondervan Publising House, 1971, 325 pages.

Iain Murray, The Invitation System, Carlisle, The Banner of Truth Trust, 1967. $\mathrm{Pb} 40$ pages.

John R. W. Stott, Between Two Worlds: The Art of Preaching in the Twentieth Century; Grand Rapids, Wm. B. Eerdmans Publishing Co., 1982, 351 pages. 